\title{
Tinjauan pustaka The Importance of Parent - Infant Bonding towards Infant Mood Regulation
}

\author{
Tjhin Wiguna \\ Departemen Ilmu Kesehatan Jiwa Fakultas Kedokteran Univesitas Indonesia/RS Dr. Cipto Mangunkusumo, Jakarta
}

\begin{abstract}
Bonding atau ikatan emosi antara orangtua dan anak usia di bawah tiga tahun ( anak usia batita) merupakan suatu ikatan timbal balik yang sangat penting bagi tumbuh kembang seorang anak. Teori yang berkaitan dengan bonding ini sudah dijelaskan sejak beberapa dekade yang lalu namun peran dalam praktik klinik masih dirasakan terbatas. Bonding sudah mulai terbentuk sejak bayi dalam kandungan dan berlangsung terus sampai beberapa tahun kemudian. Oleh karena itu setiap gangguan yang terjadi sejak masa kandungan sampai dengan lahirnya anak dapat mengganggu proses keseimbangan ikatan orangtua - anak usia batita ini, sehingga berdampak dalam proses perkembangan dan regulasi emosi anak. Klaus dan Kennell menyatakan bahwa ikatan antara ibu - anak usia batita ini dapat berlangsung optimal jika bayi dan ibu dipersatukan sedini mungkin segera setelah lahir. Disregulasi mood pada anak usia batita merupakan salah satu contoh adanya gangguan keseimbangan ikatan ibu - anak usia batita; kondisi tersebut membuat anak usia batita mengalami kesulitan dalam menyesuaikan dirinya terhadap berbagai jenis perasaan dan rangsangan yang berkaitan dengan pengalaman emosionalnya, terutama dalam kaitan dengan pengalaman emosional yang bersifat negatif. Disregulasi mood yang tidak tertangani cenderung membuat pertumbuhan bayi terganggu dan dapat berdampak terhadap terjadi nya ganggal tumbuh dari anak tersebut, dan tentunya juga mengakibatkan terganggunya perkembangan anak. Oleh karena itu, deteksi dini dari permasalahan ikatan ibu - anak usia batita ini sangat penting dikenali sehingga intervensi dini dapat diberikan dalam usaha untuk mencapai pertumbuhan dan perkembangan anak yang optimal serta perbaikan derajat kesehatan ibu pada umumnya terutama dalam kaitan dengan kesehatan jiwa ibu. Sari Pediatrī 2016;17(6):478-84.
\end{abstract}

Kata kunci: parent-infant bonding, disregulasi mood, anak usia batita, ikatan emosi ibu-anak usia batita

\section{Review Article The Importance of Parent - Infant Bonding towards Infant Mood Regulation}

Tjhin Wiguna

\begin{abstract}
Mother - infant bonding is a reciprocal emotional relationship that contributes significantly towards infant development. The theoritical review of bonding has been mentioned since several decades but the implemention in clinical practices is still not consistently applied. The mother - infant bonding develops from pregnacy until several years later after the baby is borned. Nevertheless, each problems that occur during that period have an effect on mother - infant bonding development and later on might give an impact on infant mood development and regulation respectively. Klaus and Kennel mentioned that mother - infant bonding develops optimally if the rooming in between mother and baby starts soon after the delivery. Disequilibrium towards bonding development might trigger an infant mood dysregulation that makes an infant couldn't cope with the external stimulation and his/her subjective experience especially in relation with the negative emotional experience. Infants with mood dysregulation tend to grow inoptimally and will further experiences failure to thrive; on the other hand, they also tend to be under develop compared to other infants. Early detection on mother - infant bonding development is a must in order to support the maternal mental wellbeing and an optimal infant growth and devlopment. This paper try to discuss the mother - infant bonding development especially related with the infant mood development. Sari Pediatri 2016;17(6):478-84.
\end{abstract}

Keywords: parent-infant bonding, mood dysregulation, infant, mother - infant bonding

\footnotetext{
Alamat korespondensi: Dr. dr. Tjhin Wiguna, SpKJ(K). Divisi Piskiatri Anak dan Remaja Departemen Ilmu Kesehatan Jiwa FKUI/RSCM. Jalan Kimia 2/35, Jakarta 10430 - Indonesia Tel. +62-213107741. E-mail: twiga00@yahoo.com
} 


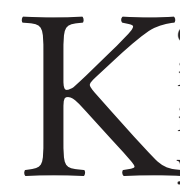

emampuan manusia untuk membentuk ikatan baik secara fisik dan emosi dengan individu lain merupakan suatu kondisi kesehatan jiwa setiap individu tidak terkecuali antara orangtua dan anak usia batita. Pola asuh yang tepat merupakan salah satu komponen fundamental dalam mengembangkan ikatan emosi antara orangtua dan anak yang sehat. Mengingat pentingnya pola asuh ini, tidak heran banyak studi yang dilakukan dalam usaha untuk memahami lebih lanjut mengenai pola penyesuaian yang terjadi baik pada anak maupun orangtuanya yang meliputi faktor biologis dan psikologis dalam usaha untuk mencapai keseimbangan sehingga anak dapat berkembang lebih optimal.

Sejak awal sebagai individu yang matang, seorang calon orangtua terutama seorang calon ibu sudah mulai mempersiapkan diri terutama dalam aspek emosional terhadap keputusan nya untuk mempunyai anak. Muatan emosional ini berlangsung terus menerus sejak kehamilan sampai dengan lahirnya anak dan tidak pernah terhenti walaupun sang anak sudah berkembang menjadi dewasa. ${ }^{1}$

Istilah bonding sebagaimana yang dikemukakan oleh Kennell, dkk (1976) ${ }^{2}$ merupakan suatu ikatan emosi antara ibu dengan bayinya yang bersifat resiprokal dan mulai terbentuk sejak kontak pertama antara ibu dengan bayinya. Ikatan ini dilaporkan berkembang terus sejak awal terjadinya yaitu segera setelah anak dilahirkan, serta berlanjut terus beberapa tahun kemudian dan memberikan dampak yang besar bagi perkembangan anak selanjutnya. Orangtua membentuk bonding atau ikatan emosi timbal balik dengan sang bayi melalui kasih sayang, perhatian, pengasuhan, perlindungan dan afeksi yang sesuai dengan kebutuhan bayi. Adanya bonding yang optimal antara orangtua dan anak usia batita membuat mereka mampu menjalin kelekatan yang sehat dengan orangtuanya dan menimbulkan perasaan aman dalam diri mereka sehingga dikatakan memberikan dampak positif terhadap perkembangan emosi, sosial dan kognitif anak selanjutnya. ${ }^{3-5}$

Proses terbentuknya ikatan emosi timbal balik antara orangtua - anak merupakan hal yang sangat penting bagi seorang anak, terutama pada anak usia batita. Dalam suatu penelitian dilaporkan bahwa anak usia batita cenderung lebih muda melekat dengan orangtuanya, dilain pihak orangtua pada umumnya memerlukan waktu yang bervariasi oleh karena adanya berbagai macam perasaan yang muncul segera setelah anak dilahirkan. Beberapa orangtua dapat langsung membentuk bonding atau ikatan emosi yang kuat dengan bayi mereka segera setelah bayi dilahirkan, sedangkan bagi orangtua yang lain mungkin belum memerlukan periode waktu tertentu; terutama jika bayi memerlukan perawatan begitu dilahirkan atau adanya masalah kesehatan jiwa pada orangtua. ${ }^{1,2}$

Istilah lain yang berkaitan dengan ikatan emosi antara orangtua - anak adalah kelekatan (attachment) yang dikemukakan oleh John Bowlby. ${ }^{6}$ Kelekatan adalah setiap bentuk perilaku yang menghasilan suatu keterdekatan secara emosional antara satu individu dengan individu lain yang dipilih dan disukai, biasanya dimulai pada usia 9 bulan pertama kehidupan. Bowlby menjelaskan bahwa bertambah sering anak berinteraksi dengan seseorang maka kemungkinan kelekatan dengan individu yang bersangkutan bertambah besar. ${ }^{6}$ Schaffer dan Emerson dalam penelitiannya menjelaskan bahwa 29\% anak usia batita mampu membentuk kelekatan dengan beberapa tokoh yang berperan dalam kehidupan mereka secara simultan. Mereka juga melaporkan bahwa pada usia sekitar 18 bulan, $87 \%$ anak usia batita telah berhasil membentuk kelekatan multipel dan sepertiga dari jumlah tersebut membentuk kelekatan dengan 5 atau lebih tokoh yang berperan dalam kehidupan anak.

Pengaruh kelekatan terhadap pola perkembangan perilaku, kognitif, keterampilan sosial, dan respons emosi serta karakter anak sudah tidak dapat diragukan lagi. Sroufe and Jacobvitz $(1989)^{7}$, menyimpulkan bahwa pengalaman anak terhadap proses perkembangan kelekatan dengan figur utama dalam kehidupan mereka berkaitan dengan luaran akhir dari perkembangan anak itu sendiri serta dapat bersifat sebagai faktor protektif atau risiko terhadap pengaruh trauma di kemudian hari. Schore $(2001)^{8}$ menyatakan bahwa pengalaman dini tersebut akan membentuk perkembangan karakter anak sebagai individu yang unik, kemampuan adaptasi mereka serta kerentanan dan resistensi mereka terhadap berbagai bentuk tantangan di kemudian hari.

Dengan demikian, ikatan emosi antara orangtua - anak dan proses perkembangan kelekatan anak usia batita dengan orangtua atau pengasuh utamanya merupakan dua kondisi yang terpenting dalam perkembangan anak selanjutnya termasuk dalam perkembangan regulasi emosi itu sendiri. Sebagai seorang bayi yang baru dilahirkan maupun sebagai anak usia batita, mereka dikatakan tidak mampu untuk 
berkembang hanya dengan kemampuan diri mereka sendiri. Mereka membutuhkan orangtua/pengasuh yang kompeten serta memberikan perhatian dan mengasuh mereka dengan penuh perhatian dan kasih sayang. Hal ini bahkan sudah dicetuskan oleh Winnicott sejak tahun 1965 "A baby alone does not exist". ${ }^{4}$ Freiberg menuliskan bahwa; "identitas personal seseorang yang merupakan hal yang paling utama dari aspek kemanusiaan hanya dapat dicapai melalui ikatan emosi awal antara orangtua dan anak'. Frieberg juga menuliskan bahwa hati nurani seseorang yang merupakan kondisi pencapaian yang paling manusiawi dari evolusi manusia, ternyata tidak hanya dicapai secara genetik konstitusional namun justru ditimbulkan oleh kasih sayang orangtua dan pendidikan. ${ }^{1}$

\section{Pembentukan ikatan emosi antara orangtua - anak}

Klaus dan Kennel (1982) $)^{9}$ mengemukakan bahwa istilah 'bonding' yang merujuk pada proses jangka panjang dari perkembangan ikatan emosi antara anak dengan orangtuanya yang sudah dimulai sejak awal kelahiran seperti yang dikemukakan oleh beberapa studi terdahulu. Dengan demikian dapat disimpulkan bahwa

1. Ada perubahan yang sistematik dalam respons maternal menyusul segera setelah bayi dilahirkan seperti perasaan bahagia, sedih, kekawatiran atau respons emosi lain yang terjadi akibat tanggung jawab baru yang harus dipikul segera setelah bayi lahir.

2. Perasaan tersebut mempunyai efek berkelanjutan terhadap perilaku orangtua dalam mengasuh anak selanjutnya.

Dengan demikian, dapat dikatakan bahwa baik maternal - infant bonding maupun parental - infant bonding merupakan suatu kondisi yang terjadi secara bertahap dan merupakan proses berkesinambungan, dan berkaitan dengan berbagai faktor yaitu baik dari faktor anak dan faktor ibu atau faktor orangtua serta sangat tergantung pada periode perkembangan anak itu sendiri. Proses perkembangan maternal - infant bonding dapat dikatagorikan dalam 4 tahapan ${ }^{4}$, yaitu;

1. Tahap pertama merupakan tahap individuasi. Pada akhir tahap ini, seorang anak usia batita mampu untuk mengatasi perasaan lapar, ber- adaptasi terhadap sensasi dingin atau hangat dan megembangkan persepsi visualnya menjadi lebih baik.

2. Tahap ke dua, anak usia batita mulai mengembangkan kemampuan untuk memberikan respons yang tepat terhadap semua stimulus sosial yang datang dari sekitarnya. Dengan kemampuannya ini, anak usia batita terampil untuk membedakan antara objek hidup manusia dan benda mati lainnya.

3. Tahap ke tiga merupakan tahapan terakhir. Anak usia batita mulai menguasai berbagai keterampilan untuk bersosialisasi, seperti tersenyum, bergumam sehingga mampu menarik perhatian lingkungan sekitar. Dalam konteks ini anak sudah mulai mampu beradaptasi dengan lingkungan sekitarnya, terutama dengan orang yang sudah dikenal. Dalam tahapan ini, tergantung juga dari seberapa besar paparan sosial yang diterima oleh anak tersebut, jika paparan yang diterima banyak orang, kuat dan cukup bermakna maka anak usia batita ini mampu mengembangkan kelekatan dengan berbagai orang yang ada didekatnya.

4. Tahap ke empat, anak mulai mengembangkan harapan terhadap berbagai figur pengasuhnya. Dengan adanya berbagai respons interaksi dengan figur yang dikenal anak maka anak usia batita ini mempelajari dan mulai mengembangkan perasaan percaya dengan orang serta lingkungannya. Konsep ini merupakan dasar terbentuknya bonding atau ikatan emosi antara anak dan ibu atau antara anak dengan orangtuanya. Perasaan percaya dengan orang yang ada di sekitar anak usia batita ini mulai dikuasai bayi sejak pada usia 6 - 9 bulan, sehingga di usia ini bayi mampu untuk menarik diri atau bersembunyi di balik orangtuanya ketika berhadapan dan bertemu dengan orang yang tidak dikenalnya.

\section{Regulasi emosi pada anak usia batita}

Perkembangan sosial-emosional anak usia batita dimulai dengan proses pembelajaran anak dalam meregulasi emosinya. Kopp (1989) ${ }^{10}$ mengemukakan bahwa ditahun pertama kehidupannya, seorang bayi berusaha untuk mempelajari dan menyesuaikan diri dengan berbagai cara untuk mengatasi berbagai perubahan melalui interaksi dengan orangtua atau 
pengasuhnya. Kemampuan ini membantu mereka untuk meredakan berbagai reaksi emosi negatif serta menguatkan emosi positif. Orangtua atau pengasuh pada umumnya mengubah lingkungan dan memberikan pola asuh yang tepat untuk bayi tersebut untuk belajar sehingga stimulasi yang diberikan berjalan sesuai dengan karakter bayi tersebut.

Bayi yang dapat menerima semua stimulasi yang diberikan pada umumnya dapat menguasai semua tahapan perkembangan ditahun pertama kehidupannya dengan optimal dan menjadi modal dasar untuk berlanjut ke tahapan perkembangan berikutnya. Sejumlah studi mengatakan bahwa bayi mampu mengembangkan kemampuan regulasi emosi ditahun pertama kehidupannya dengan adanya ikatan emosi yang optimal antara orangtua - anak sehingga terjadi kelekatan yang bersifat aman (secure attachment $)^{11}$. Kondisi tersebut menjadi modal dasar anak untuk mampu melewati fase otonomi dan menyelesaikan fase saparasi-individuasi (saparation-individuation) pada tahun kedua dan ketiga dengan lancar.

Regulasi emosi adalah kapasitas seseorang untuk memonitor, mengevaluasi, dan memodifikasi reaksi emosi dalam diri mereka selama proses pencapaian tujuan yang diharapkan. ${ }^{9}$ Kemampuan ini terbentuk melalui keserasian modulasi emosi antara ikatan orangtua dan anak yang dapat diekspresikan secara jelas dalam bentuk ekspresi wajah, vokalisasi, dan aktivitas psikomotor. Oleh karena itu, regulasi emosi mempunyai kaitan erat dengan setiap reaksi emosi yang timbul selama proses interaksi berlangsung, baik dari segi awitan, durasi dan intensitas bangkitan emosi antara orangtua dan anak usia batita. Kondisi ini juga berkaitan erat dengan temperamen anak dan karakter orangtua/pengasuh.

Anak dikatakan mempunyai regulasi emosi yang baik jika mempunyai kemampuan untuk mengekspresikan emosinya terhadap berbagai stimulasi eksternal. Cohn dan Tronick (1983) ${ }^{12}$ dalam penelitian mereka terhadap bayi sehat berusia 3 bulan dengan kemampuan regulasi emosi yang baik, serta mempunyai ibu dengan gangguan depresi yang mempunyai kecenderungan menolak dan bersikap dingin terhadap bayi tersebut; setelah beberapa saat berinteraksi dengan bayinya, tampak bayi menunjukkan perilaku protes dan marah, curiga dan menolak semua tindakan ditujukan kepada dirinya. Cohn dan Tronick menjelaskan bahwa kondisi tersebut merupakan pemicu timbulnya gejala depresi pada bayi tersebut jika orangtua/pengasuh tidak menyadari reaksi ini. Kondisi ini dikatakan bersifat reversibel, jika lingkungan dapat memenuhi kebutuhan emosi bayi tersebut dengan optimal maka gejala-gejala depresi tersebut juga menghilang.

\section{Faktor risiko dan dampak}

Beberapa faktor risiko yang berkontribusi terhadap perkembangan bonding/ikatan emosi anak usia batita dengan orangtuanya, di antaranya,

Faktor risiko perkembangan anak

- Kondisi kesehatan anak usia batita, termasuk temperamen anak. Kondisi kesehatan anak usia batita merujuk pada pola perilaku tertentu dari anak di usia ini seperti pola tidur yang teratur, periode tidur, mengantuk, aktivitas bangun dan kewaspadaan bayi yang tidak aktif, menangis atau penyakit fisik lainnya.

- Di lain pihak, temperamen anak yang sulit diasuh serta cenderung mempunyai masalah dalam regulasi diri membuat ibu merasa tidak kompeten dan frustrasi. Ke dua kondisi di atas sangat menentukan kemampuan anak untuk mengenali dan memberikan respons yang tepat terhadap figur orang yang ada di sekitarnya. Para ibu atau orangtua sebenarnya sudah menyadari bahwa anak cenderung memberikan respons yang berbeda walaupun stimulus yang mereka berikan sama, sebagai contoh pada saat anak sedang dalam kondisi tidak sehat, rangsangan yang biasanya memberikan reaksi kegembiraan pada anak berubah menjadi rangsangan yang membuat anak menjadi iritabel dan tantrum. Oleh karena itu sebagai orangtua atau seorang ibu haruslah mampu mengenali kondisi ini sehingga dapat memberikan stumulus yang sesuai dengan kebutuhan anak ${ }^{4}$.

- Anak dengan temperamen yang iritabel dilaporkan lebih banyak mengekspresikan emosi negatif (misalnya menangis kuat, menjerit dan cederung banyak merengek), terutama jika orangtual pengasuh terlalu cepat atau lambat berespons terhadap sinyal yang dikirimkan anak, jika ini berlang-sung terus tentunya akan mempengaruhi perkembangan regulasi emosi serta karakter anak di kemudian hari. Dengan demikian, strategi dan karakter orangtua dalam mengasuh anak tentunya 
berbeda antara anak yang satu dengan yang lain dan juga tergantung dari dari jenis temperamen anak dan hasil interaksi keduanya akan menentukan kemampuan anak dalam meregulasi emosinya.

- Adanya gangguan perkembangan atau penyakit kongenital tertentu pada bayi juga mempengaruhi perkembangan bonding itu sendiri. Kondisi ini membuat pupusnya harapan orangtua terhadap bayi mereka. Orangtua mempunyai kemungkinan lebih besar menjadi putus asa, marah, kecewa, takut, terus berharap dan tidak jarang jatuh dalam kondisi depresi yang tentunya dapat mempengaruhi perkembangan ikatan emosi orangtua - anak tersebut dan berakibat terjadinya regulasi emosi anak sehingga permasalahan yang timbul bertambah kompleks.

Faktor risiko yang berasal ibu

- Salah satu kondisi yang seringkali dilaporkan dan dapat menggangu perkembangan regulasi emosi pada anak usia batita adalah ketidakmampuan orangtua dalam mengenali dan memberikan respons yang sesuai dengan sinyal yang dikirimkan anak. Kropp dan Hayes (1987) ${ }^{13}$ dan Zaenah $(1998)^{14}$ menyimpulkan bahwa orangtua atau pengasuh sebaiknya dapat mengenali dan menginterprestasikan berbagai respons emosi yang datang dari seorang anak, seperti emosi takut, gembira, cemas, dan marah. Untuk mampu mengenali berbagai respons emosi tersebut, orangtua harus terlibat langsung dalam pola pengasuhan anak tersebut.

- Penelitian lain menyatakan bahwa peran ayah dalam perkembangan regulasi emosi juga sangat penting. Ayah pada umumnya memberikan stimulasi yang cenderung lebih 'aktif' dan bersifat fisik jika dibandingkan dengan stimulasi yang datang dari ibu. Jenis stimulasi ini diperlukan oleh anak untuk memodulasi bangkitan emosi anak, serta membantu anak untuk memngembangkan kemampuan mengontrol emosinya sebelum reaksi emosi anak menjadi disregulasi. ${ }^{15,16}$

Beberapa kondisi ibu yang berkontribusi terhadap regulasi emosi anak usia batita adalah

- Tindakan anestesia umum pada saat melahirkan juga dilaporkan dapat memberikan dampak negatif terhadap proses pembentukan bonding ini. Beberapa studi melaporkan bahwa pemberian anestesi umum dalam proses persalinan menurunkan responsivitas bayi dan juga mempengaruhi kondisi bayi secara keseluruhan sehingga bayi dilaporkan lebih tidak aktif jika dibandingkan bayi yang lahir tanpa pengaruh dari anestesi ini. Kondisi ini membuat proses inisiasi bonding menjadi lebih lambat, oleh karena bayi yang kurang responsif cenderung menginduksi ibu atau orangtua menjadi tidak responsif juga sehingga berdampak dalam perkembangan kelekatan antara anak dan orangtua/ibunya sehingga menjurus kepada terjadi kelekatan yang tidak aman (insecure attachment). ${ }^{17}$

- Gangguan jiwa pada ibu atau salah satu orangtua, seperti skizofrenia, gangguan depresi, atau gangguan cemas, serta gangguan kesehatan fisik pada orangtua atau ibu, seperti malnutrisi atau penyakit fisik kronik. Ke dua kondisi ini berkaitan erat dengan penurunan kapasitas orangtua dalam proses pengasuhan anak. Kondisi ini diperburuk jika orangtua, terutama ibu memerlukan perawatan yang lama segera setelah bayi dilahirkan sehingga proses iniasiasi terhadap perkembangan bonding terganggu. Rèjean, dkk $(1998)^{18}$ yang mengemukakan bahwa inisiasi bonding sedini mungkin segera setelah bayi dilahirkan dengan menggunakan Kangaroo Mother Care (KMC) membuat persepsi ibu terhadap anaknya berubah menjadi lebih baik dan secara positif merangsang perkembangan bonding menjadi lebih optimal. Disamping itu, adanya mother - infant bonding yang sangat dini dalam KMC membuat ibu merasa lebih kompeten dan responsif dalam mengasuh bayinya,

- Orangtua atau ibu yang tidak sensitif terhadap kebutuhan anak usia batita, sikap yang egosentrik sehingga tidak mau mengerti dan tidak memahami makna hadirnya seorang bayi dalam kehidupan keluarga. Penelitian terdahulu menunjukkan bahwa ibu yang mempunyai pengalaman deprivasi pada masa kecil seringkali tidak mampu menunjukkan kasih sayang dan pengasuhan yang adekuat terhadap bayi mereka oleh karena minimnya pengalaman masa kanak terhadap kedua hal tersebut akibat kurangnya ikatan emosi pada saat itu. Kondisi tersebut membuat seorang individu tidak mampu mengembangkan insting sebagai orangtua atau ibu di kemudian hari. ${ }^{19,20}$

- Stresor psikososial tertentu seperti tidak mempunyai pekerjaan tetap sehingga mempengaruhi 
kondisi keuangan keluarga, atau kondisi perumahan yang buruk sehingga cenderung menimbulkan masalah penelantaraan dan kekerasan. Wanita hamil tanpa dukungan suami atau tanpa dukungan keluarga lainnya juga merupakan salah satu stresor psikososial yang dapat memicu terjadinya gangguan dalam proses perkembangan bonding. Kondisi ini seringkali dikaitkan dengan ketidaksanggupan orangtua atau ibu untuk menyesuaikan diri dengan peningkatan tanggung jawab yang harus dipikul serta pola pengasuhan yang harus dihadapi setelah bayi dilahirkan. ${ }^{21}$

Dampak yang seringkali muncul akibat masalah parental-infant bonding adalah terbentuk-nya insecure attachment yang ditandai oleh beberapa bentuk perilaku eksternalisasi seperti agresif, menentang, menghindar, kemarahan, hostilitas atau perilaku imatur lainnya. Disamping itu, anak usia batita dengan insecure attachment dapat juga menunjukkan perilaku yang terinhibisi dan sangat tergantung dengan lingkungan sekitar, termasuk orangtuanya.

Beberapa jenis insecure attachment yang mungkin terjadi adalah, ${ }^{11}$

- Avoidant attachment berupa sikap anak usia batita yang cenderung menolak kontak dengan pengasuh utamanya setelah dipisahkan untuk beberapa saat, mereka juga cenderung acuh pada saat pengasuh utamanya pergi. Mereka tampak acuh pada saat berada lingkungan baru dan tidak memperlihatkan perilaku protes sama sekali. Mereka tampak asik dengan dirinya sendiri dan berusaha mengeksplorasi lingkungan di sekitarnya walaupun sebenarnya mereka merasa tidak nyaman yang ditunjukan dengan sikap menyendiri dan menolak setiap pendekatan yang ditujukan kepda dirinya. Dalam kondisi ini rekasi emosi anak usia batita cenderung terbatas, labil dan iritabel.

- Resistant atau ambivalent attachment ditandai oleh adanya ambang toleransi terhadap stres yang rendah dan merasa tidak yakin bahwa orangtua atau ibu akan datang untuk memberikan ketenangan kepada mereka. Ketika anak usia batita mengalami tekanan, mereka akan berusaha mencari pengasuhnya dengan tujuan untuk melampiaskan kemarahan atau kekecewaannya, serta bertahan untuk menolak setiap kontak yang diberikan. Anak dengan gambaran resistant atau ambivalent attachment dapat menunjukkan sikap menarik diri atau justru sangat tergantung dengan lingkungan sekitarnya. Mereka juga cenderung menunjukkan emosi yang tidak stabil, cenderung banyak menangis, menunjukkan sikap merengek, menuntut, ambivalen, serta menjadi jenuh oleh kebutuhan dukungan emosinya sendiri.

- Disorganized atau disoriented attachment seringkali ditandai oleh perilaku anak yang inkonsisten dan kontadiktif. Sikap dan perilaku lainnya berupa agresivitas, pola perilaku disruptif, disorganisasi. Regulasi emosi anak menjadi terganggu berupa timbulnya kecemasan dan ketakutan bertemu dengan orang asing sehingga anak cenderung menjadi labil dan iritabel.

\section{Kesimpulan}

Bonding atau ikatan emosi antara orangtua atau ibu dan anak usia batita merupakan suatu kondisi yang penting dalam proses perkembangan dan regulasi emosi anak. Oleh karena itu inisiasi dini dari bonding ini sangat penting dilakukan segera setelah anak lahir. Berbagai penelitian mengemukakan bahwa beberapa faktor yang berasal dari ibu maupun anak usia batita memegang peranan penting dalam proses perkembangan bonding ini, seperti tempera-men anak, penyakit kongenital, gangguan mental baik pada ibu maupun anak, serta berbagai masalah psikososial lainnya. Dampak dari permasalahan bonding ini adalah dalam proses perkembangan kelekatan anak usia batita dengan orangtuanya sehingga terbentuk suatu kelekatan yang tidak aman (insecure attachment) sehingga mencetuskan disregulasi emosi pada anak usia batita tersebut.

\section{Daftar pustaka}

1. Goldberg S. Parent - infant bonding: another look. Child Development 1983; 54:1355-82.

2. Kennell JH, Jerauld R, Wolfe H, Chesler D, Kreger NC, McAlpine W, dkk. Maternal behavior one year after early and extended post-partum contact. Dev Med Child Neurol 1974;16:172-9.

3. Klaus MH. Commentary: An early, short, and useful sensitive period in human infant. Birth Berkerley Calif 2009;36:110-2.

4. Spinner MR. Maternal - infant bonding. Can Fam 
Physician 1978; 24:1151-3.

5. Klaus M. Mother and infant: Early emotional ties. Pediatrics.1998;102: 1244-6.

6. Bowlby J. The making and breaking of affectional bonds. I. Aetiology and psychopathology in the light ofattachment theory. Br J Psychiatry 1977;130:201-10.

7. Sroufe, L. A. \& Jacobvitz, D. Diverging pathways, developmental transformations, multiple etiologies and the problem of continuity in development. Human Development 1989; 32:196-204.

8. Schore AN. Effect of a secure attachment relationship on right brain development, affect regulation, and infant mental health. Infant Mental Health J 2001;22:7-66

9. Klaus, M. H., \& Kennell, J. H. Maternal-infant bonding. St. Louis: Mosby; 1982.

10. Kopp CB. Regulation of distress and negative emotions: A developmental view. Developmental Psychology. 1989;25:343-54.

11. Beebe B, Jaffe J, Markese S, Buck K, Chen H, Cohen P, $\mathrm{dkk}$. The origins of 12-month attachment: a microanalysis of 4-month mother-infant interaction. Attach Hum Dev 2010;12:3-141.

12. Cohn JF, Tronick EZ. Three months old infants' reaction to simulated maternal depression. Child Development 1983;54:334-5.

13. Kropp JP, Haynes OM. Abusive and non-abusive mothers' ability to identify general and specific emotion signals of infants. Child Development 1987;58:187-90.

14. Zaenah C. Emotional development: Perspectives on the role of maternal perceptions of emotions and internal working models of attachment. Discussant of symposium presented at the biennial International Conference on Infant Stuides, Atlanta. 1998.

15. Volling BL, Belsky. Infant, father, and marital antecedents of infant fanther attachment security in dual earner and single earner families. Int J Behav Develop 1992;15:83100.

16. Diener M, Mangelsdorf SC, McHaleJL, Frosch CA. Mother-father differences and paternal correlates of infant emotion regulation. Paper presented at the biennal International Conference on Infant Studies. Atlanta, 1998.

17. Beebe B, Jaffe J, Markese S, Buck K, Chen H, Cohen $\mathrm{P}$, dkk. On the Origins of Disorganized Attachment and Internal Working Models: Paper II. An Empirical Microanalysis of 4-Month Mother-Infant Interaction. Psychoanal Dialogues 2012;22:352 -74.

18. Réjean T, Cristo M, Velez S, Girón M, Figueroa de Calume Z, Ruiz-Palàez JG, dkk. Kangaroo mother care and the bonding hypothesis. Pediatrics 1998;102:17-25.

19. Beebe B, Steele M, Jaffe J, Buck K, Chen H, Cohen P, Kalz M, et al. 6. Maternal anxiety symptoms and mother - infant self- and interactive contingency. Infant Mental Health J 2011;32:174-206.

20. Kim BR, Stifter CA, Philbrook LE, Teti DM. Infant emotional regulation: Relations to bedtime emotional availability, attachment, security and temperament. J Fam Psychol 2014;28:1-11.

21. Beebe B, Steele M. How does microanalysis of motherinfant communication inform maternal sensitivity and infant attachment. Attach Hum Dev. 2010. doi:10.1080/ 14616734.2013.841050. 